\begin{tabular}{llr} 
KULTURA & POLSKA A KADEMIA NAUK & ISSN 0023-5172 \\
i & KOMITET SOCJOLOGI & \\
SPOLECLENSTWO & $\begin{array}{l}\text { INSTYTUT STUDIÓW POLITYCZNYCH } \\
\text { 2020, nr 3 PROJEKTOWANIE DZIECIŃSTWA }\end{array}$ & \\
\hline
\end{tabular}
$\begin{array}{llllllll}A & R & T & Y & K & U & 亡 & Y\end{array}$
I
$\begin{array}{llllllll}\mathbf{R} & \mathrm{O} & \mathrm{Z} & \mathbf{P} & \mathrm{R} & \mathrm{A} & \mathrm{W} & \mathrm{Y}\end{array}$

MAJA BRZOZOWSKA-BRYWCZYŃSKA

Uniwersytet im. Adama Mickiewicza w Poznaniu

\title{
DZIECIŃSTWO: PROJEKT W KRYZYSIE
}

\section{PORĘCZNOŚĆ POJĘCIA KRYZYSU, ODRĘBNOŚĆ DZIECIŃSTWA}

Pojęcie kryzysu jest ważnym, jeśli nie formatywnym, tworzywem rozmaitych projektów społecznych dzieciństwa. Nierzadko pojawiają się one przecież $\mathrm{w}$ odpowiedzi na uprzednio zdefiniowane zagrożenia, czy to ze strony kultury i systemu społecznego, które upośledzają harmonijny rozwój dzieci, czy ze strony samych dzieci w ten czy inny sposób zaburzających ład społeczny i hierarchię wartości kulturowych. Pojęcie kryzysu jest również poręcznym narzędziem radzenia sobie z konsekwencjami dychotomicznego zderzenia konstruktów dzieciństwa i dorosłości. Pełni rolę błędnika, przywracając równowagę między nimi i chroniąc przed koniecznością redefinicji oddzielającej je granicy. Kryzys stanowi rodzaj soczewki, poprzez którą możemy przyglądać się współczesnemu dzieciństwu, lokować je w sieci relacji społecznych, zwłaszcza w relacji do dorosłości. Jednocześnie pojęcie kryzysu dzieciństwa pozwala filtrować i podświetlać przemiany w rodzinie, kulturze i społeczeństwie późnej, płynnej nowoczesności, akcentując najdotkliwsze zaburzenia równowagi między światem dzieci a światem dorosłych.

Brytyjski socjolog dzieciństwa Michael G. Wyness zauważa w Contesting Childhood (2002), że współcześnie dominującymi komponentami dys- 
kursu o dzieciństwie są niepokój (związany z nadużyciami dorosłych wobec dzieci) oraz ambiwalencja (dotycząca głównie kwestii statusu dziecka $\mathrm{w}$ podlegającym obecnie dynamicznym i gwałtownym zmianom świecie). Towarzyszą temu nasilające się problemy związane $z$ wykreślaniem granic między dzieciństwem a dorosłością, a także coraz powszechniejsze owych granic kontestowanie. Zdaniem Wynessa (2002, s. 1), kontekst ten sprzyja formułowaniu tez o kryzysie dzieciństwa, zwłaszcza jeśli postrzega się je przez pryzmat dorosłości - jako jej rewers. Inaczej mówiąc, zwłaszcza jeśli sądzi się, że dzieciństwo jest po prostu tym, czym nie jest dorosłość. Faktycznie, dzieciństwo nierzadko opisywane jest w kategoriach przeciwieństw, zazwyczaj związanych z brakami czy to społecznych kompetencji, czy moralnych walorów, czy wreszcie wiedzy i doświadczeń po stronie dzieci, a braki te determinują hierarchiczne relacje między dzieciństwem i dorosłością. Jednocześnie kulturowy obraz dzieciństwa bywa też ucieleśnieniem dorosłych pragnień wolności od społecznych uwarunkowań bądź niewinności utraconej $\mathrm{w}$ toku dorastania czy wyrazem inwestycji w pełen nadziei projekt lepszej przyszłości. LuAnn Walther (1979, s. 64) ujmuje to następująco: „[...] dzieciństwo, ów wynalazek dorosłych, w takim samym stopniu odzwierciedla dorosłe potrzeby i dorosłe lęki, jak i oznacza zanik dorosłości. W toku historii dzieci bywały przedmiotami uwielbienia, obiektami patronizujących praktyk, doświadczały obojętności i odrzucenia, w zależności od założeń kulturowych, jakie na ich temat mieli akurat dorośli". Interpretowanie współczesnego dzieciństwa z użyciem kategorii kryzysu może sugerować, że te założenia kulturowe coraz mniej odpowiadają złożonej nowoczesnej rzeczywistości dzieciństwa, że - posiłkując się sformułowaniem Wynessa (2002, s. 8) - dzieci są coraz bardziej „nie na miejscu" w polu hierarchicznych relacji i wizji wspartego na nich ładu społecznego konstruowanego przez dorosłych.

Jak wskazuje Jane Pilcher (1995), nowoczesne zachodnie dzieciństwo, od czasu jego wynalezienia w XVIII wieku, konstruowane jest $\mathrm{w}$ dyskursie publicznym i akademickim przede wszystkim z użyciem kategorii odrębności (por. Ariés 1995; Cunningham 1995). Odrębność przyjmuje formę społecznej, kulturowej, politycznej i ekonomicznej zależności od dorosłych, a jednocześnie wolności od dorosłych obowiązków i odpowiedzialności oraz izolacji od problemów dorosłego świata. Przejawia się również w specyficznym ulokowaniu doświadczeń dzieci, przypisanych do prywatnych przestrzeni domu, miejsc zabawy i instytucji edukacyjnych, a wykluczonych z publicznych przestrzeni życia politycznego oraz rynku pracy.

Rozwijany na fundamencie tego kluczowego oddzielenia teoretyczny konstrukt dzieciństwa generuje dość sztywną przestrzeń koncepcyjną, 
w której narracje kryzysowe służą głównie jako legitymizowane narzędzie wyjaśniania rozmaitych przesunięć granic między światami doświadczeń dzieci i dorosłych - czy będzie to adultyzacja dzieci czy infantylizacja dorosłych (zob. Łaciak 2011; Bogunia-Borowska 2006; Barber 2008). Warunkiem oddzielenia jest możliwość jasnego wykreślenia granic, możliwość posłużenia się wyraźnymi różnicami, co z kolei wymaga uznania niezmienności, czystości przeciwstawianych sobie zjawisk. Pojęcie kryzysu uruchamia mechanizmy paniki moralnej, mobilizując poszukiwania kozła ofiarnego, winnego ewentualnego zaburzenia dotychczasowego ładu (Kehily 2010, s. 177). Dzieje się tak w dużej mierze dlatego, że przy dychotomicznej relacji dzieciństwa i dorosłości, które stają się swoimi „konstytutywnymi zewnętrzami” (Mouffe 2008, s. 34), brakuje miejsca na niebinarne, nieesencjalistyczne ujęcia, pozwalające nie tylko zobaczyć dzieciństwo i dorosłość z perspektywy fundujących je różnic, ale także dostrzec obszary wspólnych doświadczeń i współzależności. Włączenie pojęcia kryzysu do diagnozy dzieciństwa jest więc tyleż propozycją wyjaśnienia tego, co się dzieje (a w efekcie - stworzenia przestrzeni narracji i działań przywracających dotychczasowy porządek), ile niemożnością uznania ambiwalencji, złożoności koncepcji dzieciństwa i doświadczeń bycia dzieckiem we współczesnym świecie. Stwierdzenie, że dzieciństwo jest w kryzysie, sugeruje, że istnieje jakiś „przedkryzysowy” model dzieciństwa, który można zidentyfikować i na jego podstawie przeciwdziałać zaburzeniom równowagi społecznej. Jednocześnie jest to model, który lokuje dzieciństwo w mitycznej przestrzeni poza rasą, klasą, płcią oraz innymi wymiarami tożsamości, wyraźnie różnicującymi i multiplikującymi doświadczenia społeczne dzieci i wpływającymi na zajmowane przez nie miejsce zarówno w rzeczywistości społecznej, jak i w kryzysowej narracji. Być może zmiany w doświadczeniach współczesnego dzieciństwa, związane chociażby $z$ rozwojem technologii, specyfiką otaczającej kultury czy transformacjami relacji $\mathrm{w}$ rodzinie, są definiowane $\mathrm{w}$ kategoriach kryzysu z uwagi na niedostateczną obecność (czy też niedostateczną gotowość do używania) w dominującym dyskursie i wyobraźni społecznej języka, który pozwalałby uchwycić płynność analizowanych kategorii, podważyć oczywistość ich wzajemnych relacji (zob. np. Lee 2001).

Chris Jenks (2002), porządkując historię narracji o współczesnym dzieciństwie, proponuje przypisać je do dwóch opozycyjnych obrazów kulturowych, które mimo że nie wyczerpują opisów różnorodnych formatów dzieciństwa, jednocześnie najbardziej uruchamiają publiczne i naukowe dyskursy rozwijane $\mathrm{w}$ celu jego zrozumienia. To dzieciństwo dionizyjskie $z$ jednej i apollińskie $z$ drugiej strony. Pierwszy obraz — oparty na popula- 
ryzowanej przez filozofię purytańską koncepcji grzechu pierworodnego opisuje „małego diabła”, dzikie, nieposłuszne, uparte dziecko, które dąży do zaspokajania własnych potrzeb, nie licząc się z wymogami życia społecznego. Jest jak freudowskie id, które kieruje się zasadą przyjemności, nie bacząc na rzeczywistość i stanowi źródło psychicznej energii, potencjalnie destrukcyjnej nie tylko dla niego samego, ale przede wszystkim chyba dla ustalonego porządku społecznego. Należy je zatem zdyscyplinować i odpowiednio zsocjalizować, żeby w toku tych zewnętrznych wysiłków uzyskało status istoty społecznej. Drugi - mocno zakorzeniony w rozwijanym od czasów oświeceniowych przeświadczeniu o dziecięcej czystości i niewinności - ilustruje „dziedzic słońca i światłości, oblubieniec poezji i piękna” (Jenks 2002, s. 73). Przypisuje się mu łagodność i wrodzone dobro, które $\mathrm{w}$ konfrontacji z dorosłym światem mogą zostać naruszone bądź zniszczone. Cechuje go jasność i prostota spojrzenia, nieskażone społecznymi schematyzmami, gloryfikowane przez dorosłych jako to, co w człowieku najlepsze. Tym, co mimo przeciwstawnych treści łączy te obrazy, jest wpisana w ich konstrukcję konieczność kontroli dziecka ze strony dorosłych, opieki, troski i projektowania jego rozwoju. Projekty naprawcze dotyczą bądź społeczeństwa i kultury, dostarczających dzieciom potencjalnie szkodliwych wartości i niebezpiecznych wzorów postępowania, bądź samych dzieci — których nie poddana dorosłej kurateli społeczna obecność grozi załamaniem istniejącego ładu. Wskazują tym samym na potencjalne źródła kryzysu wpisane w opozycję dzieciństwa apollińskiego i dionizyjskiego - lęk o dzieci i lęk przed dziećmi.

\section{KRYZYS JAKO STAŁY ELEMENT KRAJOBRAZU DZIECIŃSTWA}

Dychotomia dzieciństwa dionizyjskiego i apollińskiego ilustruje, w założeniu Chrisa Jenksa, zarówno ambiwalencję postaw wobec dzieci, rozpiętych między postrzeganiem ich bądź jako z natury złych, bądź jako z natury dobrych, jak i historię zmian w koncepcji dzieciństwa - od uprzedmiotowienia do upodmiotowienia, od dyscypliny do miłości. W pewnym sensie podobne rozumienie historii dzieciństwa proponuje perspektywa psychohistoryczna. Lloyd DeMause, jeden z jej czołowych przedstawicieli, stoi na stanowisku, że „historia dzieciństwa jest koszmarem, z którego jako ludzkość dopiero zaczynamy się budzić" (DeMause 1974, s. 1). W toku tej historii wymienia on sześć etapów zmiany postaw dorosłych wobec dzieci, ewolucję od okrucieństwa do empatii: rodzicielstwo dzieciobójcze (od antyku do wieku IV), rodzicielstwo porzucające (dominujące do XIII wieku), rodzicielstwo ambiwalentne (w wiekach XIV-XVI), ro- 
dzicielstwo natrętne, intruzywne (wiek XVIII), socjalizujące (wiek XIX - połowa XX) i wreszcie współczesne - rodzicielstwo pomocne (zob. też Golus 2019). DeMause jest przekonany, że przemiany te stanowią źródło zmian historycznych, niezależne i bardziej istotne od czynników społecznych czy technologicznych. Ewolucja stosunku rodziców do dzieci — od codzienności morderstw i molestowania, przez emocjonalną obojętność, kary cielesne jako narzędzie cywilizowania, nacisk na dyscyplinę i posłuszeństwo, instytucjonalizację dziecięcych doświadczeń, aż po wychowanie stawiające dziecko oraz jego potrzeby w centrum - jest przez niego postrzegana jako efekt zdolności kolejnych pokoleń rodziców do dokonywania $\mathrm{w}$ procesach wychowawczych regresji do wieku psychicznego dzieci i ponownego przepracowywania dziecięcych lęków, a więc jako proces zasadniczo naprawczy. Jednocześnie kolejne zbliżenia między rodzicami i dziećmi mają generować niepokój tych pierwszych w wyniku wzrostu świadomości potrzeb drugich, a próby redukcji tych lęków o różnej intensywności i specyfice - stanowią podstawowe źródło kształtowania się typowych dla kolejnych epok sposobów wychowywania dzieci. Przywołuję tu ten model dlatego, że pozwala on potraktować kryzys nie tylko jako zjawisko nowoczesne, ale jako immanentną składową formułowania dyskursów dzieciństwa, pokazując, jak modele myślenia o dzieciach i ich relacjach $z$ dorosłymi wyrastały $w$ toku historii z jednych kryzysów, generując zarazem kolejne napięcia i zaburzenia równowagi.

„Stulecie dziecka”, proklamowane w 1900 roku przez Ellen Key (1928), prekursorkę reformy pedagogicznej, miało u podstaw założenie, że dzieciom należy zrekompensować dotychczas doświadczane przez nie cierpienia i nadużycia ze strony dorosłych oraz że od skupienia się na dziecku oraz pielęgnowania dzieciństwa, walki o jego prawo do rozwoju zgodnie $z$ naturą zależy dobre życie nas wszystkich. Konstytutywne dla nowego stulecia miało być uznanie, że od tego, w jaki sposób dorosłe społeczeństwo traktuje dzieci, zależy jego przyszłość (zob. Cunningham 1995). Dziecko miało być przewodnikiem, nauczycielem dorosłych, wiązano $z$ nim wielkie nadzieje na odnowę społeczeństwa, zwracano uwagę na jego wyjątkowość, a także na kruchość i ufność, które mogą stać się przyczyną dziecięcego nieszczęścia. Barbara Smolińska-Theiss (2010, s. 18) pisze: „pajdocentryzm doceniał, ale i przeceniał możliwości, role i znaczenie dziecka, budował nieuzasadnione mity i wizje”. Można sądzić, że przynajmniej po części z powodu takiej narracji o dzieciństwie u progu XX wieku kolejne jego opisy uciekały się do słownika kryzysu, a kryzys ten miał dotyczyć nie tylko negatywnych zmian związanych z rozwojem nowoczesnych społeczeństw, ale odsyłał również do niespełnionych obietnic dorosłych wobec 
dzieci oraz przywiązania do „nieuzasadnionych mitów i wizji” w kreśleniu kolejnych obrazów dzieciństwa.

Paradoksalnie bowiem - mimo rozwoju katalogów dziecięcych praw, obowiązkowej scholaryzacji, prawnej ochrony przed pracą, wzrostu przeżywalności niemowląt i znacznej poprawy zdrowia dzieci - wiek XX, nazywany w dyskursie pedagogicznym „zagrażającym”, jest uznawany za najgorszy w historii. Być może właśnie dlatego zasłużył na taką diagnozę, że nie sposób już wyjaśnić cierpień dzieci brakiem wiedzy naukowej, prawodawstwa czy polityk społecznych, które miałyby je chronić przed nadużyciami dorosłych. Wbrew założeniom Ellen Key przyniósł on: „[...] masowe dzieciobójstwo, wyzysk dzieci, maltretowanie, ustawiczne eksperymentowanie $z$ ich psychiką, uczuciami, edukacją, osamotnienie, wykluczenie, konieczność podejmowania ciężkiej pracy, odpowiedzialności za bliskich, głód, niedożywienie, choroby (np. ponowne zagrożenie gruźlicą, próchnicą), zagubienie, zagrożenie bezpieczeństwa i tożsamości" (Waloszek 2003, s. 892).

Historia zmieniających się narracji o dzieciństwie - tutaj zaledwie naszkicowana i niekompletna — pokazuje, że kryzys towarzyszył mu w zasadzie zawsze, a na pewno zawsze dotyczył jakiejś części dziecięcych doświadczeń. Romantyczna wizja dziecka - opiewanego w poezji Williama Wordswortha jako „ojciec człowieka” — każąca widzieć w nim niewinną, naturalną istotę o wyjątkowym spojrzeniu na świat, jeszcze nie spaczonym dorosłym racjonalizmem i konformizmem, rozwijana była niemal w tym samym czasie, w którym w wiktoriańskiej Anglii dzieci z klasy robotniczej umierały $z$ wycieńczenia, dosłownie niosąc na swoich barkach rewolucję przemysłową. Przepisy dotyczące zakazu zmuszania do pracy najmłodszych dzieci, zatrudniania dzieci do pracy ponad ich siły, prawa do godziwej płacy i unormowanego dnia roboczego, znane jako Factory Acts (1833), można uznać za jedno z pierwszych prawnych rozwiązań problemu wykorzystywania dzieci jako taniej siły roboczej, a co za tym idzie jedną z pierwszych prób prawnego uregulowania ich szczególnego statusu. Podobnym kryzysowym kontekstem wyłaniania się idei dziecka jako podmiotu praw i istoty wymagającej ochrony przed nadużyciami dorosłych jest historia Mary Ellen Wilson (zob. Shelman, Lazoritz 2004). Sprawa jej maltretowania przez rodziców zastępczych, rozpatrywana $-z$ braku ustawodawstwa dotyczącego dzieci - na podstawie przepisów dotyczących przeciwdziałania okrucieństwu wobec zwierząt, stała się pretekstem 
do powołania w 1874 roku pierwszej na świecie organizacji ochrony dzieci przed przemoca, Nowojorskiego Towarzystwa Przeciwdziałania Okrucieństwu wobec Dzieci, i punktem zwrotnym w historii praw dziecka. Również tekst pierwszej deklaracji praw dziecka z 1924 roku, zaproponowany przez Eglantyne Jebb, powstał w odpowiedzi na dziecięce traumy z okresu pierwszej wojny światowej. Ochrona dzieci — ofiar głodu, chorób, sieroctwa i cierpień - była postrzegana przez tę reformatorkę jako moralny obowiązek dorosłych, rodzaj odkupienia win. Przykłady te ukazują generalnie kryzysowy grunt, na którym wyrosły nowoczesne koncepcje dzieciństwa.

Powszechnie uznana jest teza, że dzieciństwo stanowi konstrukt społeczny (James, Prout 1997; James, Prout, Jenks 1998; Jenks 2002), którego treść oraz granice są zależne od czasu historycznego i miejsca kulturowego, w jakim jest ono konceptualizowane i doświadczane, że wyrasta na gruncie przekonań i systemów wartości występujących w konkretnych kontekstach społecznych. Wytwarza to mnogość ostatecznie nieporównywalnych, kulturowo ukorzenionych dzieciństw. Jednocześnie w dyskusji na temat kryzysu dzieciństwa, w pytaniach o jego specyfikę i lokalizację, można zauważyć zderzenie dwóch wizji rozwoju kryzysowej narracji. W dużym uproszczeniu można określić je jako perspektywę rozwiniętych krajów Zachodu i rozwijających się krajów globalnego Południa. O ile w pierwszym przypadku, do czego jeszcze tu wrócę, kryzys ten wiąże się głównie ze specyfiką gwałtownych przemian w kulturze późnej nowoczesności, które sprawiają, że dzieciństwo kończy się zbyt szybkim zderzeniem z rzeczywistością wygórowanych oczekiwań dorosłych czy wpływem wszechobecnych mediów i konsumpcji, o tyle w drugim dzieciństwo kończy się zbyt szybko z zupełnie innych powodów. Publikowany co roku przez organizację Save the Children raport End of Childhood Index wskazuje na osiem kluczowych czynników zagrażających dzieciństwu, wykreślających tym samym główne osie jego kryzysu w skali globalnej. Jest to śmiertelność dzieci do piątego roku życia, niedożywienie wiążące się zahamowaniem wzrostu, brak dostępu do edukacji, zmuszanie do pracy, przymuszanie, zwłaszcza dziewczynek, do małżeństw i przemoc seksualna, nastoletnie ciąże, doświadczenia konfliktów zbrojnych oraz dzieciobójstwo. Wskaźniki te odsyłają jednocześnie pośrednio do minimalnych wymogów „normalnego" dzieciństwa, rozpatrywanego z perspektywy uniwersalistycznej jako doświadczenie wspólne wszystkim dzieciom, niezależnie od kulturowego kontekstu ich dorastania. Najdalej od tak wykreślonej normalności, przypisane $\mathrm{w}$ rankingu End of Childhood Index do kategorii największego ryzyka „utraty dzieciństwa”, są głównie kraje kontynentu afrykańskiego; 
a te państwa, w których ryzyko takie jest najmniejsze zazwyczaj lokują się w Europie, z kilkoma wyjątkami, jak Singapur i Korea Południowa ${ }^{1}$.

Należy zauważyć, że ranking ten, choć odwołuje się do obiektywnych wskaźników dobrostanu dzieci żyjących w różnych częściach świata, jest jednocześnie wyrazem dominacji zachodniocentrycznego sposobu postrzegania dobrego, normalnego dzieciństwa oraz zestawu potrzeb i warunków, w których może być ono realizowane (zob. Milne 2015). Uniwersalistyczna perspektywa globalnego dzieciństwa, znajdująca pełen wyraz w zapisach Międzynarodowej Konwencji o Prawach Dziecka, przyjmowana jest w rozmaitych projektach „ratowania dzieciństwa” skierowanych zwłaszcza do dzieci z krajów „Trzeciego Świata”, bez uwzględnienia wielości pozaeuropejskich dzieciństw i ich społeczno-kulturowych lokalizacji (zob. Nieuwenhuys 2008; Hanson 2014; Nsamenang 1999), a tym samym lokuje narracje o kryzysie tyleż w polu obiektywnych opisów warunków życia dzieci w skali globalnej, ile w przestrzeni wartościujących sądów o tym, jak dzieciństwo powinno wyglądać pod każdą szerokością geograficzną. Jednocześnie również $\mathrm{w}$ opisie współczesnego zachodniego dzieciństwa w kryzysie (Matyjas 2008, s. 40 i nast.) pojawiają się takie określenia, jak „dzieciństwo zagrożone” (głównie brakiem opieki rodzicielskiej stale bądź przejściowo, z wielorako rozumianym sieroctwem, prowadzącym do osamotnienia dziecka w rodzinie), „dzieciństwo zranione” (zaniedbane, doświadczające przemocy, w tym przemocy i nadużyć seksualnych) czy „dzieciństwo gorszych szans" (będące udziałem dzieci ulicy, dzieci ze społecznych marginesów), co sugeruje, że być może dychotomizacja kryzysów „pierwszego” i „trzeciego” świata jest złudna. Bożena Matyjas zestawia te obrazy dzieciństwa $z$ leżącymi na drugim biegunie formatami dzieciństwa nadmiaru, rozpuszczonych dzieci, w którym brak relacji z najbliższymi jest zastępowany konsumpcją i treściami medialnymi, zaznacza przy tym, że terminy te nie są rozłączne zakresowo ani nie układają się w żaden ciąg ewolucji sposobów doświadczania dzieciństwa, ale współistnieją i krzyżują się, składając się na skomplikowany obraz rozmaitych zagrożeń dla rozwoju dzieci we współczesnym świecie.

\section{ZNIKANIE WSPÓŁCZESNEGO DZIECIŃSTWA}

Znikanie dzieciństwa - szczególną odsłonę jego współczesnego kryzysu - można ujmować jako koniec możliwości bezdyskusyjnego loko-

${ }^{1}$ https://www.savethechildren.org/content/dam/usa/reports/advocacy/global-childhoo d-report-2019-pdf.pdf [dostęp: 01.09.2020]. 
wania go w dychotomicznej parze $\mathrm{z}$ dorosłością, pewności co do założeń o odrębnym statusie dziecka i odrębności jego świata społecznego. Ta swoista depedagogizacja dzieciństwa oznacza, że problemy, z którymi w toku swoich doświadczeń mierzą się dzieci, dotyczą nie tylko kwestii ich niedojrzałości czy niekompetencji wyłączających z wielu przestrzeni życia społecznego, ale przeciwnie - wyrastają z nadmiernej obecności świata dorosłych w doświadczeniach dzieciństwa, z gęstniejących zależności między doświadczeniami dzieciństwa a gwałtownymi i rozległymi przemianami społecznymi, kulturowymi, politycznymi oraz technologicznymi nowoczesnych społeczeństw. Mają związek z nowymi układami rodzinnymi, które zmieniają status dziecka $\mathrm{w}$ rodzinie, $\mathrm{z}$ nowymi wzorami konsumpcji i funkcjonowaniem w rzeczywistości społecznej nasyconej mediami.

Turbulencje kulturowe, polityczne i społeczne lat sześćdziesiątych $\mathrm{XX}$ wieku, a także datowany na lata siedemdziesiąte zwrot kulturowy, zmobilizowały obszar humanistycznej narracji oraz politycznej praktyki do problematyzacji takich pojęć, jak płeć czy rasa. Co jednak symptomatyczne, analogiczne problematyzacje dzieciństwa nie zostały umieszczone $\mathrm{w}$ kategoriach emancypacji, jak w przypadku rozwoju narracji genderowych czy rasowych, ale wpisano je w opowieść o utracie jego właściwej natury, zanikaniu tych aspektów dzieciństwa, które budowały konstrukty dziecięcej niewinności i czystości.

Neil Postman (1982) ogłosił wspomniane znikanie dzieciństwa - i to znikanie w zatrważającym tempie - na początku lat osiemdziesiątych. Jego przyczyn upatrywał w rozmywaniu się granic, które dotychczas trzymały w ryzach dychotomię dziecka i dorosłego, pozwalając zachować porządek społeczny i hierarchię wiedzy, stanowiącą narzędzie kontroli dzieci $\mathrm{w}$ procesie wkraczania $\mathrm{w}$ świat dorosłych. Wraz z upadkiem kultury druku i wzrostem dominacji kultury medialnej dzieci miały utracić wrodzoną niewinność i naiwność na rzecz niebezpiecznej wiedzy i cynicznej postawy wobec świata. Treści przeznaczone dotychczas tylko dla dorosłych za sprawą telewizji stały się powszechnie dostępne również dla dzieci. To przesunięcie sprawiło, że dzieci zaczęły dorastać zbyt szybko, gubiąc po drodze istotę dzieciństwa, której Postman upatrywał $\mathrm{w}$ dziecięcej ignorancji. Znikanie dzieciństwa było związane $z$ niebezpiecznym przenikaniem się dzieciństwa i dorosłości, zamianą ról między dziećmi i dorosłymi, było więc przede wszystkim kryzysem kategorii. Koncepcję Postmana zasilała jedna $z$ najbardziej kuszących postromantycznych fantazji na temat dzieciństwa - idea: „preindustrialnego Złotego Wieku, idyllicznego Raju, w którym dzieci mogą oddać się beztroskiej zabawie, nieskażone zepsuciem" (Buckingham 2000, s. 35), coraz trudniejsza do utrzymania 
w obliczu gwałtownych i rozległych zmian kultury drugiej połowy XX wieku. Chociaż od czasu publikacji The Dissapearance of Childhood podejście do analizowania dzieciństwa w kontekście kultury medialnej i konsumpcyjnej przeszło pewną ewolucję (zob. np. Hermes 2005; Buckingham 2011), postmanowska perspektywa wciąż znajduje wyraz zarówno w debacie akademickiej, jak i w dyskursie publicznym (zob. np. Schor 2005; Barber 2008; Palmer 2015). Jak sugeruje Mary Jane Kehily (2010), żywotność takich kryzysowych narracji wynika $\mathrm{z}$ leżącego $\mathrm{u}$ ich podstaw zderzenia dwóch modeli: w tym wypadku wizji dzieciństwa jako okresu niewinności i czystości, w którym podstawowym prawem dziecka jest właśnie pozostawanie dzieckiem i zajmowanie odrębnej od dorosłości przestrzeni dzieciństwa oraz wyrastającej z późnonowoczesnej narracji społeczeństwa ryzyka wizji dzieciństwa jako czasu osamotnienia, niepewności i ambiwalencji, współdzielonego $\mathrm{z}$ dorosłymi $\mathrm{w}$ ramach bardziej uniwersalnego kryzysu tożsamości i bezpieczeństwa (zob. Giddens 2001; Beck 2002). To także efekt wykrystalizowania się, zwłaszcza w dyskursie dotyczącym praw dziecka, zainicjowanym przez uchwalenie w 1989 roku Międzynarodowej Konwencji o Prawach Dziecka, przeciwwagi dla dotychczas dominującego obrazu dziecka jako istoty niesamodzielnej, niedojrzałej i wymagającej troski ze strony dorosłych - a mianowicie modelu dziecka jako sprawczego i kompetentnego aktora społecznego. Uznanie dziecka za podmiot praw nie tylko do ochrony i opieki, ale również do głosu i partycypacji w życiu społecznym potencjalnie problematyzowało prostą hierarchię władzy i dychotomiczne relacje między dziećmi i dorosłymi.

\section{Toksyczność dzieciństwa}

Sugestywne pojęcie toksyczności do słownika opisu kryzysu współczesnego znikającego dzieciństwa wprowadza Sue Palmer (2015). U jego podstaw leży założenie - stanowiące echo perspektywy Postmana - że efektem ubocznym gwałtownych zmian technologicznych i kulturowych ostatnich kilku dekad są zaburzenia w rozwoju intelektualnym, emocjonalnym i fizycznym dzieci. Palmer wylicza dowody na toksyczność współczesnego dzieciństwa, układające się w sugestywny obraz jego kryzysu, oparty na utożsamieniu dyskursu dzieciństwa $z$ dyskursem niewinności.

Po pierwsze, toksyczności dowodzi komercjalizacja dzieciństwa i jego doświadczeń związana z kierowanym do dzieci natrętnym marketingiem, który skutkuje utożsamianiem szczęścia z posiadaniem rzeczy i nieumiejętnością docenienia wartości niematerialnych. Alison Pugh (2009) w komercjalizacji dzieciństwa dostrzega też formę rekompensowania przez ro- 
dziców braku czasu na bycie razem ze dziećmi. Kenneth J. Gergen, opisując przemiany trybu życia współczesnych rodzin, związane głównie z dzieleniem czasu między pracę, szkołę czy przedszkole, zajęcia dodatkowe, rozrywki i życie towarzyskie, dostrzega jednak, że mimo tego negatywnego wpływu na tradycyjny model życia rodzinnego („dom jest bardziej miejscem postoju niż gniazdem rodzinnym"; Gergen 2009, s. 98) wyobrażenia o tradycyjnej rodzinnej zażyłości pozostają istotnym sposobem budowania relacji w rodzinie. Brak czasu rekompensowany jest emocjonalną intensywnością spędzanych wspólnie momentów, powstają „związki z mikrofalówki" (Marody 2016) możliwe między innymi za sprawą rozwoju technologii i oferty konsumpcyjnej, nierzadko stanowiących jedyny łącznik między rodzicami a dziećmi, które wzorce moralne i społeczne czerpią w coraz większym stopniu również spoza rodziny, z mediów i kultury rówieśniczej.

Po drugie, dominacja kultury wizualnej i nasycenie przestrzeni socjalizacji mediami prowadzą nie tylko do upadku kultury słowa i erozji umiejętności społecznych wśród dzieci - w tym umiejętności komunikowania się twarzą w twarz, wyrażania emocji, empatii, ale także do zaburzenia relacji w rodzinie, w której treści socjalizacyjne zaczynają płynąć dwoma paralelnymi, a bywa, że pełnymi sprzecznych treści, kanałami, przy czym nierzadko, jak sugeruje Palmer, rodzice świadomie wykorzystują media jako nianie. Nasycenie kultury, również tej kierowanej do dzieci, obrazami przemocy ma skutkować ponadto wzrostem przemocowych, agresywnych zachowań wśród dzieci. Z dominacją kultury medialnej i konsumpcyjnej idzie w parze również seksualizacja dzieciństwa (Trojanowska 2014; Bieńko 2013), a zwłaszcza seksualizacja dziewczynek (Durham 2010).

Po trzecie, toksyczne skutki ma zbyt wczesna i zbyt rozległa instytucjonalizacja dzieciństwa. W narracji pedagogicznej dzieciństwo XXI wieku nosi miano „zawłaszczonego”, „sprzedanego” — przez korporacje, polityków, producentów. „Dzieciństwem manipuluje się na niespotykaną dotąd skalę. Najbardziej niebezpieczne są postawy wielu rodziców i pedagogów, którzy na taką manipulację się zgadzają. W wielu rodzinach stawia się dziecko na drodze kariery, w wielu przedszkolach dzieci przestały się bawić, uczyć się - są zabawiane (przez aktorów, magików), poprawiane (przez logopedów, korektorów, trenerów), mierzone, czy nadają się do szkoły, elektronicznie rejestrowane do przedszkoli" (Waloszek 2009, s. 139). To dzieciństwo pospieszane - do rozwoju, do nauki, do akumulacji kapitałów przydatnych w dorosłym życiu (Honoré 2011; Elkind 2001), w którym za intensywnym rozwojem intelektualnym nie nadąża rozwój emocjonalny, a dzieciom brakuje pewności siebie oraz poczucia bezpieczeństwa tożsamościowego. Ten pośpiech odzwierciedlać ma cho- 
ciażby uprzywilejowana pozycja zabawek edukacyjnych w ofercie dla dzieci czy nieustanny nacisk na rozwijanie wyobraźni i ćwiczenie kreatywności podczas różnego rodzaju warsztatów (zob. Rakoczy 2018). Zabawa traktowana jest przy tym jako inwestycja w przyszłość i w zasadzie bardzo upodabnia się do pracy i nauki. To także dzieciństwo, w którym czas wolny jest tylko pozorny, gdyż w praktyce nie istnieje poza obszarem dorosłej kontroli, co utrudnia wytworzenie się niezależnej kultury dziecięcej, przestrzeni swobodnych rówieśniczych kontaktów (Corsaro 2015).

Wiążą się z tym, po czwarte, zmiany $w$ systemie edukacji prowadzące do spadku oceny krytycznego myślenia i niezależności dzieci na rzecz kwantyfikacji wiedzy, przeładowanie programów szkolnych treściami do wyuczenia i spadek wskaźników alfabetyzmu funkcjonalnego, a także związane ze specyfiką współczesnej szkoły, skupionej na testach i rankingach, problemy psychiczne, które prowadzą do depresji, samookaleczeń, a nawet samobójstw młodych ludzi.

I wreszcie, co nie mniej istotne, składnikiem toksycznego koktajlu zatruwającego współczesne dzieciństwo jest otyłość. Stoi za nią w nie tylko niezdrowa fastfoodowa dieta, ale także brak ruchu i aktywności fizycznej. Diagnoza brzmi prosto: dzieci spędzają czas przed ekranami, zamiast bawić się z rówieśnikami na świeżym powietrzu. Analizując ten aspekt kryzysu dzieciństwa, Will Coster (2007, s. 25) wprost stawia naprzeciwko siebie „chłopców grających w piłkę na ulicy, dziewczynki pchające wózki z lalkami" i prowadzących siedzący tryb życia graczy oraz widzów, narażonych na otyłość, brak zainteresowania nauką, ekspozycję na przemoc i seks w medialnych obrazach. O ile łatwo przyczyn takiego stanu rzeczy upatrywać w lenistwie dzieci i porównywać z nostalgicznymi wersjami naszego własnego dzieciństwa, nie mniejszą rolę pełnią tutaj również tendencje projektowania przestrzeni współczesnych miast, zagęszczenie urbanistyczne i wzmożony ruch samochodowy, które powodują kurczenie się miejsc i możliwości swobodnej zabawy (Wyness 2002), dramatycznie zmniejszają autonomiczną mobilność dzieci (Shaw, Bicket, Elliott 2015), utrudniając im wytwarzanie i używanie własnych „miejsc trzecich”. Znikanie dzieciństwa, którego otyłość jest skutkiem ubocznym, można rozumieć zatem również jako znikanie dziecięcych przestrzeni wolności i zabawy, będących wyznacznikami szczęśliwego dzieciństwa. William Corsaro (2015) zauważa, że ważną rolę $\mathrm{w}$ tym procesie pełnią także lęki rodziców, wynikające $z$ wyrastającego $z$ medialnych narracji przekonania, że świat jest zły i pełen niebezpieczeństw, skutkujące wzmożoną kontrolą dziecięcych światów. Tendencja ta prowadzi do powstawania swoistej geografii lęku w wykreślanej pod jego presją przestrzeni dzieciństwa (Valentine 2004). Poczucie 
kryzysu potęguje fakt, że potrzeba ochrony dzieci przed fizycznym i psychicznym niebezpieczeństwem zostaje zderzona ze świadomością wagi swobodnej zabawy i samodzielnej eksploracji świata społecznego, co jest traktowane jako warunek harmonijnego rozwoju dziecka (zob. Clements, Fiorentino 2004).

\section{Nadmiar kontroli i osamotnienie}

Lista toksyn zatruwających współczesne dzieciństwo zapewne nie jest wyczerpująca, ale oprócz wskazania problematycznych obszarów jego doświadczania: konsumpcji, mediów, edukacji, zabawy, odsłania ciekawy aspekt myślenia o kryzysie dzieciństwa, mianowicie utożsamianie go z kryzysem tradycyjnej, nuklearnej rodziny (Elkind 2001; Beck 2002; Gergen 2009). Znikanie dzieciństwa traktowane jest przede wszystkim jako efekt uboczny zmiany relacji w rodzinie (zmieniające się modele wychowania, kultura ekspercka proponująca konkurencyjne sposoby budowania relacji z dziećmi), między rodzicami (zmiana ról społecznych matki i ojca, rozwody, alternatywne modele rodziny) - wszystko to zmusza do przemyślenia na nowo relacji między dziećmi i innymi członkami rodziny, zmiany pasa transmisyjnego socjalizacji (kwestia wychowania przez media) czy zmiany wzorów spędzania czasu wolnego (ich konsumpcyjny charakter, „związki z mikrofalówki”).

Frank Furedi, autor Paranoid Parenting (2002), wychodzi z założenia, że źródłem kryzysu rodziny są różne odsłony medialnych panik moralnych i eksperckie publikacje parentingowe głoszące kryzys w rodzinie, podkopujące tym samym poczucie rodzicielskiej pewności i wzmagające poczucie bezradności rodziców, którzy tracą wiarę w swoje kompetencje. Zdaniem Furediego, współczesne rodzicielstwo charakteryzują lęk i paranoja. Oczywistą konsekwencją paranoicznego podejścia rodziców do dzieci jest wyolbrzymianie ryzyk i nacisk na zapewnienie dzieciom bezpieczeństwa przy jednoczesnym załamaniu się solidarności między dorosłymi, którzy zamiast wspierać się i sobie ufać, postrzegają się nawzajem jako źródło potencjalnego zagrożenia. Efektem kryzysu rodziny, a zwłaszcza rodzicielstwa, jest więc dzieciństwo poddane nadmiernej kontroli ze strony dorosłych, głównie paranoicznych rodziców, dziecko pozbawione samodzielności i wolności doświadczania dzieciństwa po swojemu, podejmowania ryzyka i popełniania błędów. Kryzys dzieciństwa odnosi się jednak w społecznych diagnozach nie tylko do braku przestrzeni, w której dzieci mogły doświadczać go w sposób niezależny od dorosłej kontroli, ale wynikać może również à rebours — ze swoistego osamotnienia dziecka. 
Urlich Beck (2002) przywołuje w tym kontekście obraz „dzieciństwa supernowoczesnego”, w którym odbijają się procesy indywidualizacji społeczeństw późnej nowoczesności. Dziecko supernowoczesne staje w obliczu wielu wymagań: samodzielności, mobilności i konieczności nieustannego przystosowywania się do różnych form życia rodzinnego, wykraczających poza tradycyjny model rodziny nuklearnej. Wykonuje ono również, na co zwracał uwagę David Elkind w The Hurried Child (2001), pracę emocjonalną na rzecz swoich rodziców, którzy doświadczając różnego rodzaju kryzysów relacji i tożsamości, przenoszą na dzieci swoje problemy i frustracje. Supernowoczesne dzieciństwo biegnie paralelnie do życia rodzinnego, wypełnione zajęciami dodatkowymi, zgodnie z samodzielnie koordynowanymi grafikami, samodzielnie projektowanym rytmem; dziecko realizuje się w „wyspowych przestrzeniach” — w zróżnicowanych, niepowiązanych ze sobą miejscach angażujących różne rodzaje aktywności, inscenizuje własne kompleksowe stosunki społeczne. Dziecko mierzy się z rosnącą koniecznością kształtowania własnej biografii, a jednocześnie nieustannie dąży do sprostania wymaganiom nakładanym przez dorosłych.

„Postmodernistyczne dziecko zagrożone jest zatem, z powodu narzuconej mu często samodzielności, rozluźnieniem więzi biologicznej i emocjonalnej z rodzicami, zarówno w rodzinach biednych, jak i zasobnych (z powodu dezorganizacji rodziny wynikającej z trudnych warunków materialnych, rozwodów, konfliktów, migracji zarobkowej rodziców, patologii występujących w rodzinie, ogromnego zaangażowania rodziców w działalność zawodową)" (Cywińska 2014, s. 8). Konsekwencją tak rozumianego kryzysu jest u dzieci poczucie osamotnienia — smutek, lęk, ale też gniew i rozczarowanie, poczucie nieszczęścia, frustracje i stresy, choroby psychiczne i samobójstwa.

\section{Dzieciństwo nie na (swoim) miejscu}

Dla Michaela Wynessa (2002) podstawowym metaforycznym obrazem dzieciństwa w kryzysie jest „dziecko nie na (swoim) miejscu” (out of place). Ta dyslokacja może przyjmować bardzo różne formy: seksualizacji dzieciństwa, uczestnictwa dzieci w rynku pracy, w konfliktach zbrojnych, sytuacji dzieci z doświadczeniami uchodźczymi, osieroconych, popełniających przestępstwa. $Z$ pewnością dotyczy też niebezpiecznych z punktu widzenia wizji idyllicznego dzieciństwa przestrzeni konsumpcji i mediów, w których dzieci - nierzadko w przeciwieństwie do dorosłych - czują się swobodnie i mogą tworzyć własne kultury poza ich kontrolą. Jednak szczególnie interesujące wydaje się myślenie o kryzysie dzieciństwa jako 
dzieciństwie i dzieciach „nie na miejscu”. Przykładem mogą być nie tylko analizy zbyt szybkiego doroślenia dzieci (a więc bycia nie na miejscu w sensie dychotomii dzieciństwa i dorosłości, w wyniku tragicznych doświadczeń czy nadmiernej ekspozycji na przekazy medialne i ofertę kultury konsumpcyjnej), ale także perspektywa procesów upodmiotawiających dzieci, związanych nie tylko z przemianami w obszarze praktyk rodzicielskich, ale również $z$ domeną dziecięcych praw in genero. Bycie nie na miejscu oznacza zatem również, że dzieci stają się bardziej aktywne i sprawcze, że podważają hierarchiczny charakter relacji między dorosłością i dzieciństwem, że mają głos, są obywatelami, świadomymi i kompetentnymi aktorami społecznymi, którzy nie tylko budują w aktywny sposób swoje światy doświadczeń społecznych, ale także potencjalnie współwytwarzają przestrzenie znaczeń kulturowych. Sprawczość dzieci i ich obywatelski status to nie bez przyczyny jeden $z$ najbardziej problematycznych kontekstów dzieciństwa. Jego uznanie sugeruje niepokojącą $z$ punktu widzenia istniejącego status quo relacji między dorosłością i dzieciństwem możliwość zniwelowania czy wręcz odwrócenia hierarchii między dziećmi i dorosłymi jako aktorami życia społecznego. W tym sensie kryzys dzieciństwa może być rozumiany jako możliwy kryzys adultyzmu.

Prawa dziecka do ochrony i do opieki ze strony dorosłych przyjmowane są zasadniczo bezdyskusyjnie w dyskursie publicznym, nie podważają one, a wręcz przeciwnie, podtrzymują asymetryczne relacje między dorosłymi a dziećmi, przypisując tym drugim znaną już rolę niewinnych, kruchych istot, pierwszym zaś ich opiekunów i przewodników. Z kolei prawa dzieci do głosu, do sprawczości, obecności w życiu publicznym często postrzegane są w kategoriach gry o sumie zerowej - jako odebranie dorosłym uprawnień do kontrolowania kształtu i przebiegu nie tylko samego dzieciństwa, ale życia społecznego w ogóle. Kiedy dzieci wypowiadają się na „dorosłe” tematy, jak edukacja seksualna, prawa mniejszości czy zmiany klimatyczne, nierzadko zostają w dyskusjach publicznych sprowadzone do rangi bezwolnych, zmanipulowanych marionetek, które zamiast zajmować się nieswoimi sprawami, powinny wrócić do szkoły albo do zabawy. W kryzysie tym samym znajduje się nie tyle dzieciństwo, ile raczej jego specyficzne rozumienie - zestaw dominujących idei w polach dyskursu politycznego i akademickiego, które opierają się na istnieniu wyraźnej i podtrzymywanej dychotomicznymi definicjami granicy między dzieciństwem a dorosłością oraz na esencjalnym traktowaniu obydwu tych obszarów.

Przetaczająca się przez polskie media debata dotycząca edukacji seksualnej czy antydyskryminacyjnej nie tylko stanowi ilustrację lęków do- 
rosłych, ale pokazuje również ogromne przywiązanie do konstytuującego dzieciństwo dyskursu niewinności, ściśle sprzęgniętego z ideą kontroli treści składających się na jego doświadczenie. W dyskusjach tych pojawiają się często sformułowania „moje/nasze dzieci” oraz „normalne” dzieci i dzieciństwo, które są „demoralizowane” i „deprawowane” przez obcych (członków społeczności LGBT+, edukatorów seksualnych). I chociaż treść takiej normy pozostaje $\mathrm{w}$ zasadzie niewyartykułowana, powoływanie się na nią można potraktować właśnie jako próbę przywrócenia dzieci na właściwe im miejsce: niewinności, czystości i aseksualności. Próbę zbudowania i podtrzymania obrazu dzieciństwa, które mimo budzących niepokój gwałtownych i rozległych zmian społecznych pozostanie niezmienne, wolne od permisywistycznych wpływów współczesnej kultury zainfekowanej relatywizmem moralnym. Wizja czystego, niewinnego dzieciństwa na tak zarysowanym tle okazuje się może jedyną stałą w złożonej rzeczywistości, a hierarchiczna relacja z dziećmi być może jedyną relacją, za pomocą której możemy mieć poczucie, że tę rzeczywistość kontrolujemy.

Rozpatrywanie dzieciństwa jako przedmiotu rozmaitych kryzysów wiąże się zatem zarówno $\mathrm{z}$ dostrzeganymi $\mathrm{w}$ dyskursie pedagogicznym przemianami w rodzinie, jak i z opisywaną przez socjologów specyfiką późnej nowoczesności, z rozwojem kultury konsumpcyjnej i medialnej, ale też w zakresie praw i podmiotowości dzieci - naukowych dyskursów i debat publicznych na temat dzieciństwa. Zaburzenie równowagi między dzieciństwem a dorosłością można rozpatrywać z perspektywy trzech kluczowych objawów: za szybko (dzieci dorastają za szybko, ich dzieciństwo zbyt gwałtownie się kurczy); za dużo (przemocy, telewizji, konsumpcji, seksu, problemów dorosłego świata, ale też $-z$ drugiej strony - kontroli dorosłych); i wreszcie za mało (natury, czasu, zabawy, wreszcie - samego dzieciństwa). Znikanie dzieciństwa można rozpisać tym samym na dwie komplementarne narracje. Jedna $z$ nich opisuje dzieciństwo nieuchwytne, niezrozumiałe dla dorosłych, bo lokujące się w coraz mniej dostępnych dla nich światach technologii, konsumpcji i nowych mediów, ale też anektujące przestrzenie, które - jak przestrzeń polityki - tradycyjnie stanowią domenę dorosłości. Druga to dzieciństwo niedowidziane w swojej złożoności, ale też w swojej dziecięcości, niemające głosu, traktowane jako bierny przedmiot procesów kulturowych i socjalizacyjnych, przytłoczone nadmiarem dorosłej kontroli i troski. 


\section{KONKLUZJA: CZEGO KRYZYSEM JEST KRYZYS DZIECIŃSTWA?}

Wiele przejawów wielowymiarowego kryzysu dzieciństwa ma oczywiście postać realnych problemów, z którymi zmagają się dzieci we współczesnych zachodnich społeczeństwach. Trudno nie zgodzić się z tym, że zmiany w funkcjonowaniu rodziny, w polu edukacji czy w treściach kultury medialnej nie pozostają bez wpływu na to, jak przeżywane jest współczesne dzieciństwo, że otyłość, przemoc i zaburzenia psychiczne wśród dzieci są zagrożeniem dla ich harmonijnego rozwoju. Jednak wydaje się, że diagnozowanie ich en bloc jako kryzysu, znikania czy nawet śmierci dzieciństwa (Buckingham 2000), bez dookreślenia nie tylko - nierzadko dość specyficznych - symptomów tych zjawisk i procesów, ale także tych dzieciństw, których potencjalnie dotyka to najbardziej, odnosi się nie tylko do problemów wymagających rozwiązania. Mówi chyba bardziej o załamaniu się pewnej wizji dzieciństwa, a co za tym idzie - wspartej na niej relacji między dzieciństwem a dorosłością. Narracja o kryzysie dzieciństwa, zwłaszcza w rozumieniu postmanowskiego znikania, wyrasta więc w dużej mierze $\mathrm{z}$ wiary $\mathrm{w}$ aktualność wizji dzieciństwa opartego na dyskursie czystości i niewinności, która pozwala nie tyle zrozumieć złożoność współczesnych trajektorii dzieciństwa, ile podtrzymywać jego pewną wersję, być może wygodną z punktu widzenia porządku społecznego. Podtrzymanie tej wersji wydaje się istotne o tyle, o ile pozwala zredukować złożoność współczesnego świata, poradzić sobie $z$ towarzyszącą mu niepewnością i ambiwalencją, $z$ tempem i rozległością zmian w obszarze współczesnej kultury.

W podsumowaniu trzeba stwierdzić, że diagnozowany na rozmaite sposoby kryzys dzieciństwa można postrzegać jako dwojakie zaburzenie równowagi. Po pierwsze, to swoiste postawienie na głowie dotychczasowych relacji między dziećmi a dorosłymi, polegające na przesunięciu i rozmyciu granic między dzieciństwem a dorosłością, oraz towarzyszące temu procesy, jak infantylizacja kultury, dziecinnienie dorosłych i zbyt szybkie doroślenie dzieci. Po drugie - w konsekwencji — jest to rozziew między ideałem normalnego, szczęśliwego, beztroskiego dzieciństwa wyrosłym na gruncie jego romantycznej mitologii a nienormalnym, bo toksycznym, znikającym, osamotnionym, nadmiernie kontrolowanym, pospieszanym dzieciństwem późnej nowoczesności.

W obydwu przypadkach jednym z ważnych powodów wyłaniania się dyskursu kryzysu dzieciństwa jest właśnie dychotomiczna natura relacji dzieciństwa i dorosłości, która w pewien sposób narzuca język, generuje rozmaite odsłony paniki moralnej w akcie obrony granic i nieprzenikal- 
ności tych dwóch kategorii, związanych z nimi doświadczeń, obowiązków i praw. Wskazane symptomy dzieciństwa w kryzysie - choć oczywiście nie wypełniają puli możliwych punktów zapalnych — pokazują, że kryzys ten $w$ dużej mierze wynika $z$ nieprzyjemnej przenikalności granic, $z$ faktu, że dzieci nie są „na swoim miejscu”, zdefiniowanym przez dorosłych. Pojęcie kryzysu dzieciństwa odnosi się tym samym nie tylko do specyfiki jego współczesnych doświadczeń, ale także do doświadczeń i lęków dorosłych pojawiających się $\mathrm{w}$ odpowiedzi na przesunięcia granic między dzieciństwem a dorosłością. Mówiąc jeszcze inaczej, pojęcie kryzysu jest nie tyle czy też nie tylko narzędziem opisu współczesnego dzieciństwa, ile stanowi jeden ze sposobów zrozumienia jego heterogenicznej, ambiwalentnej, złożonej natury, redukcji jego immanentnej złożoności. Obecność kryzysu w dyskursie o współczesnym dzieciństwie jest w dużej mierze konsekwencją bardziej generalnej tendencji do postrzegania rzeczywistości społecznej w kategoriach binarnych opozycji.

Przywoływany już Michael Wyness (2002) wychodząc z założenia, że w okresie późnej nowoczesności relacje między dziećmi i dorosłymi ulegają rozległym przeobrażeniom, stwierdza jednocześnie, że niekoniecznie należy podchodzić do nich z perspektywy kryzysu, utraty, zaniku, degeneracji, ale można spróbować dostrzec pozytywne aspekty tych przemian, w których prefiguratywność kultury niekoniecznie prowadzi do negatywnie rozumianej pajdokracji, lecz raczej wymusza zagęszczanie sieci wzajemnych zależności (Cockburn 2013) między dziećmi i dorosłymi. Odejście od retoryki kryzysu wymaga jednak uznania złożoności dzieciństwa, potraktowania go jako „emergentnego wzorca działania” (Jenks 2002), co wymagałoby $z$ kolei zawieszenia idei konstytutywnego zewnętrza, jakim pojęcie dzieciństwa jest dla pojęcia dorosłości i vice versa, rozplątania tej pary dychotomicznych pojęć. Nick Lee (1999) mówi w tym kontekście raczej - niż o kryzysie - o wyzwaniu, jakie stawia przed nami współczesne dzieciństwo. Wyzwaniem tym jest zrozumienie dzieciństwa bez uciekania się do jego redukcji do antytezy dorosłości, a trudność zadania polega na tym, że - zwłaszcza w (po)nowoczesnym kontekście - podstawową cechą dzieciństwa jest ambiwalencja, a przenikanie się światów dorosłych i dzieci okazuje się coraz częściej raczej normą niż dewiacją.

Obecność narracji kryzysowej jako pewnej stałej w opisie współczesnego dzieciństwa nieuchronnie prowadzi więc, obok refleksji nad specyfiką wyzwań, jakie faktycznie stoją przed dziećmi i problemów, jakie nurtują dzieciństwo złożonej nowoczesności, również do pytania o zależność jej kształtu od pozycji - teoretycznej, ale też politycznej - z jakiej piszemy o dzieciach. Wymaga też namysłu nad tym, w jakim stopniu fakt przyj- 
mowanej za aksjomatyczną hierarchicznej i dychotomicznej relacji między dziećmi a dorosłymi, dzieciństwem a dorosłością wpływa na słownik opisu dzieciństwa. A ten wciąż raczej aktualizuje pojęcie kryzysu dzieciństwa, niż sięga po kategorię emergencji alternatywnych sposobów bycia dzieckiem $\mathrm{w}$ świecie alternatywnych form życia rodzinnego, dynamicznych, złożonych układów społecznych i kulturowych.

\section{BIBLIOGRAFIA}

Ariès Philipe, 1995, Historia dzieciństwa, tłum. Maryna Ochab, Wydawnictwo Aletheia, Warszawa.

Barber Benjamin, 2008, Skonsumowani. Jak rynek psuje dzieci, infantylizuje dorostych i potyka obywateli, tłum. Hanna Jankowska, Muza, Warszawa.

Beck Urlich, 2002, Społeczeństwo ryzyka. W drodze do innej nowoczesności, tłum. Stanisław Cieśla, Scholar, Warszawa.

Bieńko Mariola, 2013, Seksualizacja dzieciństwa w kulturze popularnej, w: Edyta Dziados (red.), Wychowanie seksualne, czyli skąd się bierze bocian? O wptywie rodziny, rówieśników, szkoty i mediów na rozwój i funkcjonowanie seksualne dzieci i młodzieży, Pracownia DTP i grafiki, Kraków.

Bogunia-Borowska Małgorzata, 2006, Infantylizacja kulturowa. Adolescencja dzieci oraz infantylizacja dorostych, w: Małgorzata Bogunia-Borowska (red.), Dziecko w świecie mediów $i$ konsumpcji, Wydawnictwo Uniwersytetu Jagiellońskiego, Kraków.

Buckingham David, 2000, After the Death of Childhood: Growing Up in the Era of Electronic Media, Polity Press, Cambridge.

Buckingham David, 2011, The Material Child: Growing Up in Consumer Culture, Polity Press, Cambridge.

Clements Rhonda L., Fiorentino Leah (red.), 2004, The Child's Right to Play: A Global Perspective, Praeger Publishers, London.

Cockburn Tom, 2013, Rethinking Children's Citizenship, Palgrave MacMillan, London.

Corsaro William, 2015, The Sociology of Childhood, 4th edition, Sage, Los Angeles.

Coster William, 2007, Childhood in Crisis, w: Paula Zwozdiak-Myers (red.), Childhood and Youth Studies, Learning Matters, Exeter.

Cunningham Hugh, 1995, Children and Childhood in Western Society since 1500, Longman Publishing Group, London.

Cywińska Małgorzata (red.), 2014, Problemy wspótczesnego dziecka. Wybrane aspekty, Wydawnictwo Naukowe UAM, Poznań.

DeMause Lloyd (red.), 1974, The History of Childhood, Psychohistory Press, Ann Arbor.

Durham Meenakshi Gigi, 2010, Efekt Lolity. Wizerunek nastolatek we wspótczesnych mediach, tłum. Mikołaj Gliński, Prószyński Media, Warszawa.

Elkind David, 2001, The Hurried Child: Growing Up Too Fast Too Soon. 3rd edition, Perseus Publishing, New York.

Furedi Frank, 2002, Paranoid Parenting: Why Ignoring the Experts May Be Best for Your Child, Chicago Review Press, Chicago.

Gergen Kenneth J., 2009, Nasycone Ja. Dylematy samości w życiu współczesnym, tłum. Mirosława Marody, Wydawnictwo Naukowe PWN, Warszawa. 
Giddens Anthony, 2001, Nowoczesność i tożsamość. „Ja” i społeczeństwo w epoce późnej nowoczesności, tłum. Alina Szulżycka, Wydawnictwo Naukowe PWN, Warszawa.

Golus Anna, 2019, Dzieciństwo w cieniu rózgi. Historia i oblicza przemocy wobec dzieci, Helion, Gliwice.

Hanson Karl, 2014, "Killed by Charity” - Towards Interdyscyplinary Children's Rights Studies, "Childhood", t. 21(4), s. 441-446.

Hermes Joke, 2005, Re-reading Popular Culture, Blackwell Publishing, Oxford.

Honoré Carl, 2011, Pod presją. Dajmy dzieciom święty spokój!, tłum. Wojciech Mitura, Drzewo Babel, Warszawa.

Izdebska Jadwiga, Szymanowska Joanna (red.), 2009, Dziecko w zmieniającej się przestrzeni życia. Obrazy dzieciństwa, Trans Humana, Białystok.

James Allison, Prout Alan (red.), 1997, Constructing and Reconstructing Childhood: Contemporary Issues in the Sociological Study of Childhood, Routledge Falmer, London.

James Allison, Prout Alan, Jenks Chris, 1998, Theorizng Childhood, Polity Press, Cambridge. Jenks Chris, 2002, Childhood, Routledge, London.

Kehily Mary Jane, 2010, Childhood in Crisis? Tracing the Contours of "Crisis” and Its Impact upon Contemporary Parenting Practices, „Media, Culture \& Society”, t. 32(2), s. 171-185.

Key Ellen, 1928, Stulecie dziecka, tłum. Iza Moszczeńska, Nasza Księgarnia, Warszawa.

Lee Nick, 1999, The Challenge of Childhood: Distributions of Childhood's Ambiguity in Adult Institutions, „Childhood”, t. 6(4), s. 455-474.

Lee Nick, 2001, Childhood and Society: Growing up in the Age of Uncertainty, Open University Press, Buckingham.

Łaciak Beata (red.), 2011, Nowe społeczne wymiary dzieciństwa, Wydawnictwo Akademickie Żak, Warszawa.

Marody Mirosława, 2016, Jednostka po nowoczesności. Perspektywa socjologiczna, Scholar, Warszawa.

Matyjas Bożena, 2008, Dzieciństwo w kryzysie. Etiologia zjawiska, Wydawnictwo Akademickie Żak, Warszawa.

Milne Brian, 2015, Rights of the Child: 25 Years After the Adoption of the UN Convention, Springer, London.

Mouffe Chantal, 2008, Polityczność. Przewodnik Krytyki Politycznej, tłum. Joanna Erbel, Wydawnictwo KP, Warszawa.

Nieuwenhuys Olga, 2008, The Ethics of Children's Rights, „Childhood”, t. 15(1), s. 4-11.

Nsamenang Bame, 1999, Eurocentric Image of Childhood in the Context of the World's Cultures, „Human Development”, t. 42(3), s. 159-168.

Palmer Sue, 2015, Toxic Childhood: How The Modern World Is Damaging Our Children And What Can We Do About It, Orion Publishing Group, London.

Pilcher Jane, 1995, Age and Generation in Modern Britain, Oxford University Press, Oxford.

Postman Neil, 1982, The Dissapearance of Childhood, Delacorte Press, New York.

Pugh Allison, 2009, Longing and Belonging: Parents, Children, and Consumer Culture, University of California Press, Oakland.

Rakoczy Marta, 2018, Polityki pisma. Szkice plenerowe z pajdocentrycznej nowoczesności, Oficyna Naukowa, Warszawa.

Schor Juliet, 2005, Born to Buy: The Commercialized Child and the New Consumer Culture, Scribner, New York. 
Shaw Ben, Bicket Martha, Elliott Bridget i in., 2015, Children's Independent Mobility: An International Comparison and Recommendations for Action, Policy Studies Institute, London.

Shelman Eric, Lazoritz Stephen, 2003, Out of the Darkness: The Story of Mary Ellen Wilson, Dolphin Moon Publishing, New York.

Smolińska-Theiss Barbara, 2010, Rozwój badań nad dzieciństwem — przełomy i przejścia, „Chowanna", nr 1.

Trojanowska Paulina, 2014, Seksualizacja dzieci i młodzieży — przyczyn, przejawy, konsekwencje i propozycje przeciwdziałania, „Dziecko krzywdzone. Teoria, badania, praktyka”, t. 13, nr 2.

Valentine Gill, 2004, Public Space and the Culture of Childhood, Taylor \& Francis, Aldershot.

Waloszek Danuta, 2009, Zawłaszczanie dzieciństwa. XXI wiek. Etiologia zjawiska, w: Jadwiga Izdebska, Joanna Szymanowska (red.), Dziecko w zmieniającej się przestrzeni życia. Obrazy dzieciństwa, Trans Humana, Białystok.

Waloszek Danuta, 2013, Dziecko, w: Tadeusz Pilch (red.), Encyklopedia Pedagogiczna XXI wieku, t. 2, Wydawnictwo Żak, Warszawa.

Walther LuAnn, 1979, The Invention of Childhood in Victorian Autobiography, w: George P. Landow (red.), Approaches to Victorian Autobiography, Ohio University Press, Athens (Ohio).

Wyness Michael, 2002, Contesting Childhood, Routledge, London.

\title{
CHILDHOOD: A PROJECT IN CRISIS
}

Maja Brzozowska-Brywczyńska

(Adam Mickiewicz University in Poznań)

\begin{abstract}
This article considers the idea of crisis as one of the key tools for conceptualizing the ambivalent nature of childhood. Although crisis narratives have been an inseparable part of describing childhood, the concept of a crisis (an end, a death) of childhood itself may refer to such different phenomena as slave labor or lack of access to education on the one hand, and the consumerist lifestyle and media addiction on the other. The author focuses mainly on the idea of the disappearance of modern childhood derived from Postman's concept. Childhood is viewed in connection with the concept of childhood's toxicity, the dichotomy between over-controlling and ignoring childhood, and the idea of childhood being inappropriate. The article concludes that although some of the problems signaled as part of the crisis diagnosis have a negative impact on the development of young people and require solutions, the idea that childhood en bloc is in crisis is rather an expression of the collapse of the classic vision of childhood, and thus of the hierarchical, dichotomous relationship between childhood and adulthood that it is based upon. The relationship thus defined does not leave much conceptual space for recognizing the complex and ambivalent nature of childhood, or for describing the changes in childhood and adulthood and their mutual determinants.
\end{abstract}

key words: childhood, crisis, disappearance of childhood

słowa kluczowe: dzieciństwo, kryzys, znikanie dzieciństwa 